\title{
Morphological and Anatomical Changes by Colchicine in Seedling of Impatiens balsamina L.
}

\author{
Ni Made Sastriyani Wiendra and Made Pharmawati* \\ Biology Study Program, Faculty of Mathematics and Natural Science, Udayana University \\ Kampus Bukit Jimbaran, Badung, Bali \\ ${ }^{*}$ Corresponding author: made_pharmawati@unud.ac.id
}

\begin{abstract}
Impatiens balsamina L. is a plant that is widely cultivated in Bali. The flower of this plant is used as a component of offering in Hindu religious ceremonies. The flower petals are thin and wilt easily, therefore genetic modification is needed to get better quality. This research aimed to study the effect of $0.01 \%$ colchicine with soaking periods of 4 hours, 8 hours, 12 hours and 24 hours to seedlings of I. balsamina. Seeds of I. balsamina were germinated and sprouted seeds were treated with $0.01 \%$ colchicine for 4 hours, 8 hours, 12 hours and 24 hours. The sprouted seeds were then transfer to polybag with soil media. The experiment was designed with randomized blok design with five replicates. Observations were done on plant height, length and width of leaf, stem diameter, number of stomata as well as observation on plant stem cortex cells. Results showed that colchicine reduced plant height at three weeks after planting, while plant stem diameter increased. Control plants had the smallest leaf length and width. The number of stomata decreased at plants derived from colchicine treated sprouted seeds and the lowest stomatal number observed was at soaking duration of 24 hours.
\end{abstract}

Keyword: colchicine, growth, Impatiens balsamina, stomata

\section{INTRODUCTION}

Impatiens balsamina is a plant whose flowers are used as ceremonial material by the Hindu community in Bali. The colour of the flowers varies greatly but is very thin and wilt quickly. Therefore, genetic improvement of $I$. balsamina is necessary to improve flower quality.

Genetic improvement can be done conventionally or non-conventionally. Conventional way is done by artificial crossing or artificial pollination. The results of crossing are expected to bring superior traits. Non-conventional genetic improvement is done by mutant selection, somatic hybridization and gene transfer [1].

One way to improve genetic of I. balsamina is by inducing polyploid. Polyploid plants are plants that have three or more sets of chromosomes in their cells [2]. The morphological characteristic of polyploid plants is bigger plants including bigger plant parts such as roots, stems, leaves, flowers and fruit [3]

Polyploid plants can be induced by various chemical compounds, one of which is colchicine. Colchicine is a toxic alkaloid extracted from the Colchinum autumnale plant. Colchicine is a mitotic inhibitor. It acts by preventing tubulin polymerization, so the separation of chromosome sets is disrupted when mitosis and cells have multiplied chromosomes [4,5].
Induction of polyploid plants with colchicine has been widely carried out. In 'Sumenep' onion, the soaking period and colchicine concentration affected the effectiveness of polyploid induction. Colchicine caused shorter onion plants, reduced the number of leaves but the leaves became thicker, reduced the amount of stomata but there was an enlargement of stomata [6].

Polyploid of Phalaenopsis amabilis seedlings can be produced by dripping colchicine 1000, 3000, 4000 and $5000 \mathrm{mg} \mathrm{L}^{-1}(0.1 \%, 0.3 \%, 0.4 \%$ and $0.5 \%)$. It was found that the most effective colchicine concentration was 5000 $\mathrm{mg} \mathrm{L}^{-1}(0.5 \%)$. Polyploid $P$. amabilis seedlings had larger stomata size than diploid seeds, and lower stomata density [7].

This research aimed to evaluate various soaking periods of colchicine $0.01 \%$ to induced morphological changes in seedlings of I. balsamina.

\section{RESEARCH METHODS}

\section{Plant Materials}

Seeds of $I$. balsamina were harvested from $I$. balsamina plantation di Sading Village, Badung Regency, Bali, Indonesia. The viability of the seeds was tested by soaking seeds in water and floating seeds were discarded while sinking seeds were treated. 


\section{Colchicine Treatment}

Seeds were germinated on three layers of filter paper in petri dish. When the radicle grew $1 \mathrm{~cm}$ long, the colchicine treatments were started.

The germinated seeds were placed between layers of filter paper saturated with $0.01 \%$ colchicine for 4 hours, 8 hours and 12 hours. After colchicine treatments, the sprouts were washed with running water.

\section{Planting, Data Collection and Analysis}

The experimental design was randomised block design with five replicates. Sprouted seeds were planted in soil media in polybag. Control plants were plants without colchicine treatment.

The parameters measured were plant height, stem diameter, the length and width of leaf and the number of stomata. The cross section of stem between treatments were also compared.

The measurement of stem diameter was done by measuring the circumference of a plant stem using thread, then the length of thread was measure using ruler. The diameter of stem was calculated from stem circumference. The observations were conducted three weeks after planting. The data were analysed using ANOVA.

\section{RESULTS AND DISCUSSION}

\section{Results}

Plant height at three weeks after planting was showed in Fig. 1. Control plant had the highest plant height $(16.12 \mathrm{~cm})$, followed by plants derived from sprouted seeds treated with colchicine for 8 hours, 12 hours and 4 hours with height of $15.54 \mathrm{~cm}, 15.84 \mathrm{~cm}$, and $15.68 \mathrm{~cm}$ respectively. The plant height among these treatments did not significantly different. Plants from sprouted seeds treated with colchicine for 24 hours had the lowest plant height $(11.82 \mathrm{~cm})$.

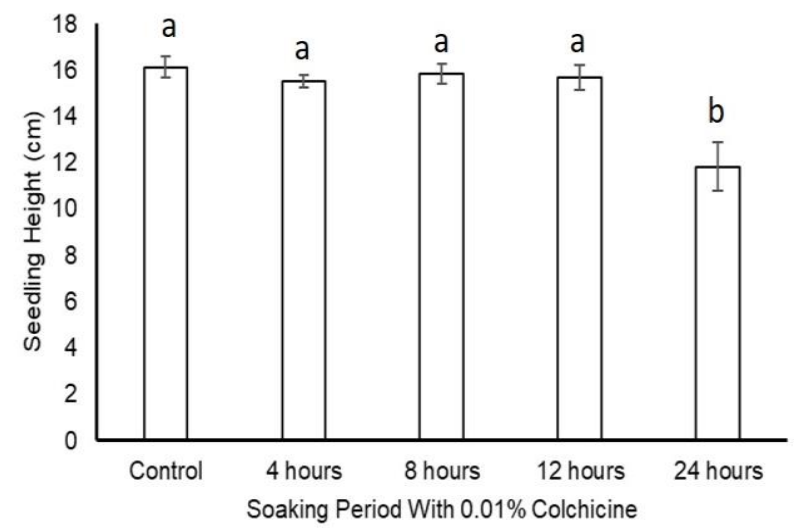

Fig 1. Plant height of I. balsamina at three weeks after planting. The error bars are standard error (SE). Histogram with same letter at the top of bar are not significantly different $(\mathrm{P}>0.05)$
Plant stem diameter varied from $0.80 \mathrm{~mm}$ to $1.27 \mathrm{~mm}$. Colchicine treatment for 24 hours resulted in plant with the biggest stem diameter, while control plant had the smallest stem diameter (Fig. 2.).

The length and width of leaf are shown in Fig. 3, Fig. 4 and Fig. 5. The longest leaf and the biggest leaf width at three weeks after planting were observed at plant resulted from 24 hours colchicine treated sprouted seeds. Control plants had the smallest leaf length. Control plant also had the smallest leaf width.

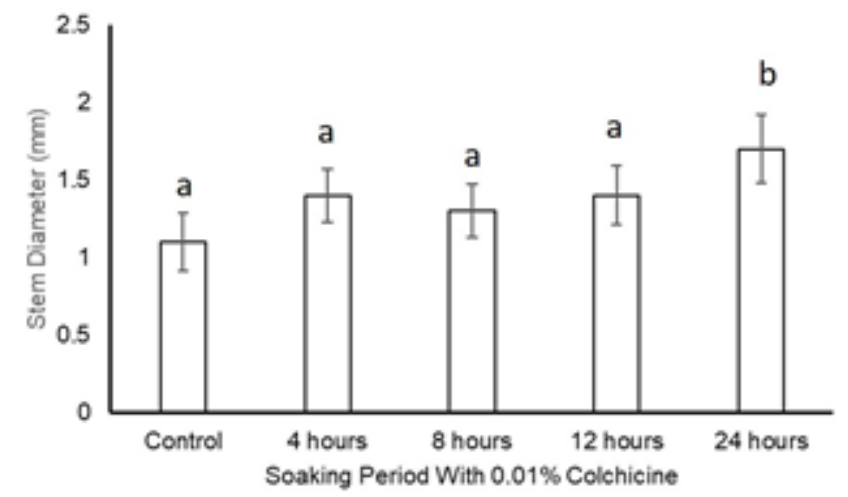

Fig 2. Plant stem diameter of I. balsamina at three weeks after planting. Error bars show standard error (SE). Histogram with same letter at the top of bar are not significantly different $(\mathrm{P}>0.05)$

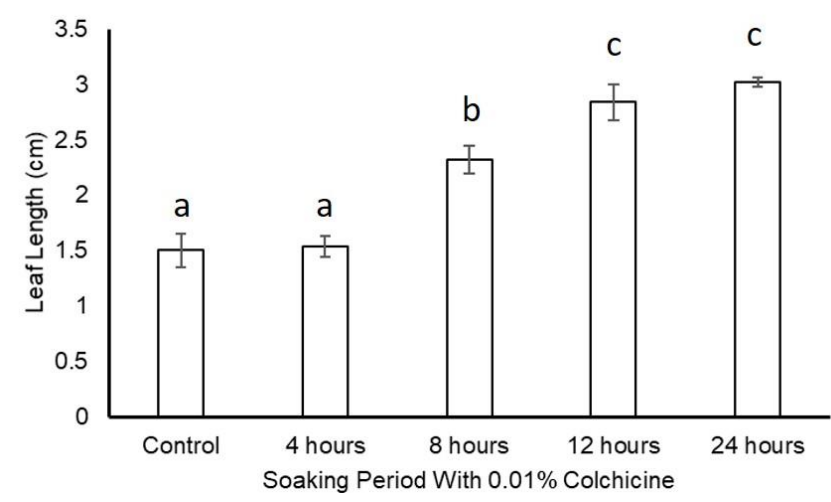

Fig.3. The length of I. balsamina leaf at three weeks after planting. Error bar is standard error (SE). Histogram with same letter at the top of bar are not significantly different $(\mathrm{P}>0.05)$

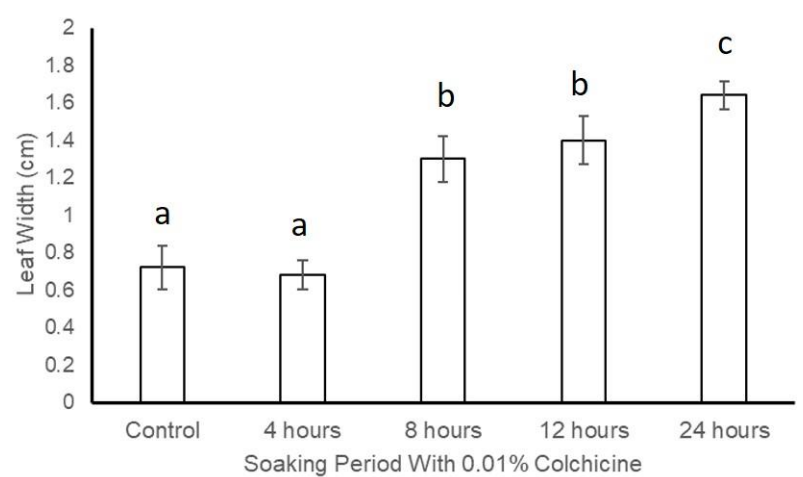

Fig 4. The width of I. balsamina leaf at three weeks after planting. Error bar is standard error (SE). Histogram with same letter at the top of bar are not significantly different $(\mathrm{P}>0.05)$ 
In Fig. 6. shows number of stomata in each treatment. Leaf of control plants had the highest number of stomata per field view of microscope. The longer the soaking time with colchicine, the smaller the number of stomata

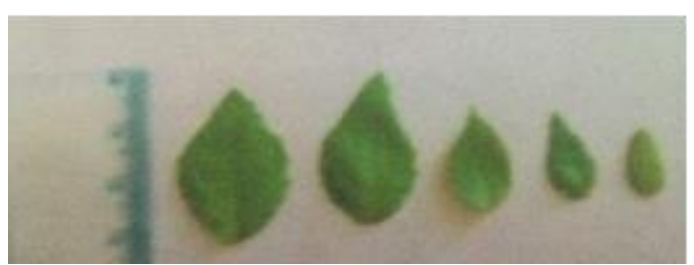

Fig 5. Comparison of plant leaves of I balsamina resulted from sprout seeds treated with colchicine. From left to right: treatment for 24 hours, 12 hours, 8 hours, 4 hours and control

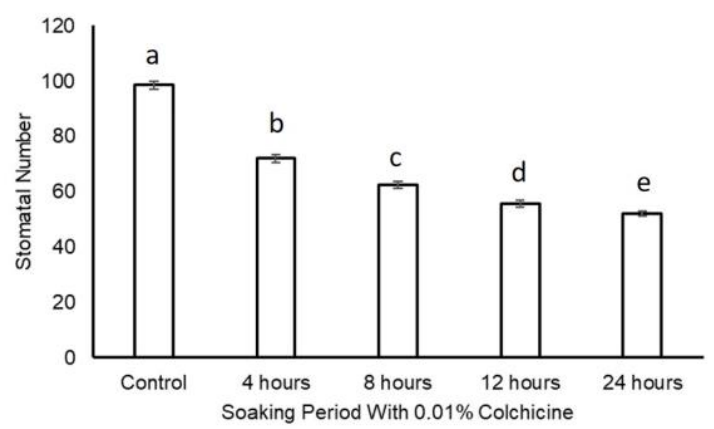

Fig. 6. Number of stomata in I. balsamina at three weeks after planting. Error bar is standard error (SE).

Histogram with same letter at the top of bar are not significantly different $(\mathrm{P}>0.05)$

The observation of stem cortex cells was conducted by preparing cross sections of plant stem and observed using microscope at magnification 200x (Fig. 7).
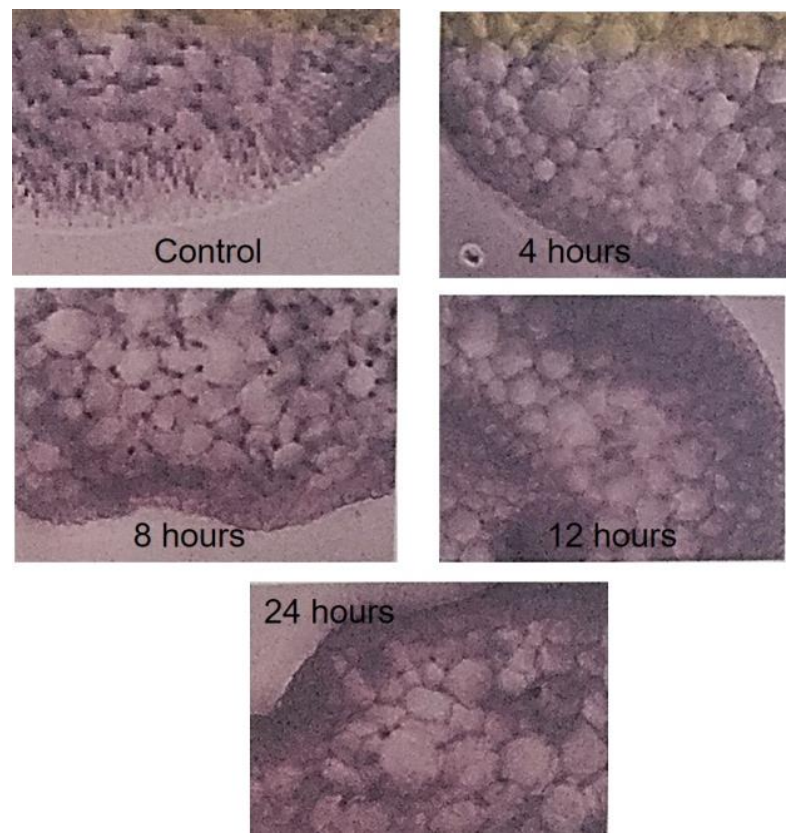

Fig. 7. Comparison of stem cortex cell of I. balsamina at there weeks after planting. Magnification 200x

\section{Discussion}

The highest value on plant height was obtained in the control plant. In the colchicine immersion treatment for 24 hours, sprouted seeds grew at the latest. At treatments of soaking for 4 hours, 8 hours and 12 hours, the sprouted seeds were able to grow equal to the control plants. The treatment of colchicine for 24 hours, resulting in inhibition of plant height due to decreased of cell division and cell elongation. The auxin produced by meristematic cells decreased due to the effect of inhibiting cell division by colchicine $[8,9]$. Treatment of colchicine in a long time resulted in inhibition of growth rates in plant height due to disruption of the mitosis and tissue damage. This results in plants taking longer to grow [10].

Leaf length and width increased due to colchicine treatment at three weeks after planting. The results of this study are in accordance with other research such as at (Polianthes tuberose), colchicine concentration of 100 ppm $(0.01 \%)$ with 9 hours soaking time and concentration level of $300 \mathrm{ppm}(0.03 \%)$ with 6 hours soaking time increased the average leaf area [11]. Research on ginger (Zingiber officinale) also found that plants with colchicine treatments had broad, long and denser leaves compared to plants without colchicine treatment [12].

Treatment with colchicine to sprouted seeds resulted in bigger plant stem than control plants. Plant stem cortex cells also appear larger in plants treated with colchicine. Study on chrysanthemum plants found that soaking chrysanthemum rooted cutting plants with colchicine $0.01 \%$ for 12 hours and 14 hours increased the diameter of the stem [13].

The number of stomata decreased in plant originated from sprouted seed treated with colchicine. The decrease in the number of stomata increases with increasing immersion time. This indicates that there was a polyploidization process. Besides chromosome counting, it was reported that the decreased of stomatal number can be used to determine polyploidy levels [14]. In marigold, treatment with $0.01 \%$ increased stomatal size and decreased stomatal number per unit area [15].

\section{CONCLUSION}

Soaking sprouted seeds with $0.01 \%$ conchicine for 24 hours resulted in lower plant height compared to control and other treatments. Soaking for 8 hours, 12 hours and 24 hours increased leaf length and width. Number of stomata decreased in all treatment.

\section{REFERENCES}

[1] Kosmiatin, M., A. Husni. 2018. Perakitan varietas Jeruk Tanpa Biji melalui Pemuliaan Konvensional dan Nonkonvensional. J. Litbang Pertanian 37(2): 91-100 
[2] Corneillie S., N. De Storme, R. Van Acker, J.U. Fangel, M. De Bruyn, R. De Rycke, D. Geelen, W.G.T. Willats, B. Vanholme, W. Boerjan. 2019. Polyploidy Affects Plant Growth and Alters Cell Wall Composition. Plant Physiol. 179(1): 74-87. doi: 10.1104/pp.18.00967.

[3] Ren, J., X. Wu, C. Song, Y. Liang, W. Gao, Y. Wang. 2018. Induction of Polyploid Tillered Onion using Colchicine and Pendimethalin. Sains Malaysiana 47(11): 2617-2624

[4] Marzougui, N., A. Boubaya, I. Thabti, W. Elfalleh, F. Guasmi, A. Ferchichi. 2011. Polyploidy induction of Tunisian Trigonella foenumgreaum L. populations. Afr. J. Biotechnol. 10: 8570-8577

[5] Kumar, M.K., M.U. Rani. 2013. Colchiploidy in fruit breeding. A review. Hortic. 2: 325-326

[6] Permadi, A.H., R. Cahyani, S. Syarif. 1991. Cara Pembelahan Umbi, Lama Perendaman dan Konsentrasi Kolkhisin pada Poliploidisasi Bawang Merah 'Sumenep'. Zuriat 2(2): 17-26

[7] Rahayu, E.M.D., D. Sukma, M. Syukur, S.A. Aziz, Irawati. 2015. Induksi Poliploidi Menggunakan Kolkisin Secara In Vivo pada Bibit Anggrek Bulan (Phalaenopsis amabilis (L.) Blume). Bul. Kebun Raya 18(1): 41-48

[8] Law, D.M., P.J. Davies. 1990. Comparative indole-3-acetic acid levels in the slender pea and other pea phenotypes. Plant Physiol. 93: 1539-1543 (1990)
[9] Ma, Y., H. Xue, L. Zhang, F. Zhang, C. Ou, F. Wang, and Z Zhanga. 2016. Involvement of Auxin and Brassinosteroid in Dwarfism of Autotetraploid Apple (Malus $\times$ domestica). Sci. Rep. 6: 26719

[10] Damayanti, Mariska. 2003. Induksi Poliploidi dengan Kolkhisin pada Hibrid F1 Hasil Persilangan Antar Spesies pada Tanaman Panili Asal Ciamis. Pusat Penelitian Biologi-LIPI, Bogor

[11] Rahayu, Y.S.S., I.K. Prasetyo, A.U. Riada. 2014. Pengaruh penggunaan kolkisin terhadap pertumbuhan vegetatif tanaman sedap malam (Polianthes tuberose L.) di dataran medium. Agromix 5 (1) 44-56

[12] Rahayuningsih, S. 2006. Pengaruh Kolkisin Terhadap Keragaan Fenotipe Dan Jumlah Kromosom Jahe Emprit (Zingiber officinale Rosc.) Asal In Vitro. Skripsi. Bogor: Fakultas Pertanian Institut Pertanian Bogor

[13] Daryono, B., W.D. Rahmadani. 2009. Karakter fenotipe Tanaman Krisan (Dendranthema grandiflorum) Kultivar Big Yellow hasil Perlakuan Kolkisin. J. Agrotropika 14(1): 15 - 18

[14] Cramer, C.S. 1999. Laboratory Technique for Determining Ploidy in Plants. HortTech. 9(4): 594-596

[15] Sajjad, Y., M.J. Jaskani, A. Mehmood, I. Ahmad, H, Abbas. 2013. Effect of Colchicine on In Vitro Polyploidy Induction in African Marigold (Tagetes erecta). Pak. J. Bot. 45(3): 1255-1258 